\title{
Religious Moderation and Information Communication Technology Dissemination: The Practice of Muhammadiyah Papua Through Online Campaign
}

\author{
Budi Santoso \\ Universitas Muhammadiyah Malang, Indonesia \\ Universitas Pendidikan Muhammadiyah Sorong, Indonesia \\ 92budisantoso@gmail.com \\ Ahsanul Inam \\ Universitas Muhammadiyah Malang, Indonesia \\ akhsanul@umm.ac.id
Abdul Haris
Universitas Muhammadiyah Malang, Indonesia \\ haris@umm.ac.id \\ Ismail Suardi Wekke \\ Institut Agama Islam Negeri (IAIN) Sorong, Indonesia \\ Asosiasi Dosen Insan Cita Indonesia, Indonesia \\ The Jusuf Kalla Research Center for Cultural Studies, Universitas Muslim Indonesia \\ iswekke@stainsorong.ac.id
}

\begin{abstract}
This article contains the efforts made by Muhammadiyah universities in Papua and West Papua related to religious moderation campaigns through information technology. There are at least three things that form the basis for the birth of this study: 1) the speed of the radicalism movement over which religion exists in the digital world; 2) potential for conflict and SARA, especially in Papua and West Papua 3) the importance of strengthening religious moderation in Indonesia, especially through digital media. The method used is library research, namely by exploring various literatures, both primary and secondary, related to the concept of religious moderation in Indonesia. The results of the study show that Muhammadiyah Papua universities in campaigning for religious moderation function as a counterweight in the digital world. That is, the narrative of religious moderation from the Muhammadiyah Papua university gave birth to a substantive and essential religious framing that is moderate and tolerant.
\end{abstract}

\section{Keywords}

Religious Moderation, Information Communication, Muhammadiyah Papua

\section{Introduction}

The Ministry of Religion of the Republic of Indonesia stated that 2019 was the year of religious moderation. In that year, religious moderation was used as a jargon and breath as well as a foothold in every program and all program policies. This means that in each of its policies and activities, it seeks to act as a mediator (moderation or wasathiyah) in the midst of diversity and pressure from the currents of disruption that have implications for all aspects of religious and national life (Harifuddin, Wekke, Zainuddin, Kamaruddin, 2018). Disputes between opposing camps pose a serious threat to the system of state order in regional, national, and even international contexts. This is a threat to diversity in a plural society. As a result of the dispute between the two camps, a number of acts of intolerance occurred 
Proceedings of the International Conference on Industrial Engineering and Operations Management Monterrey, Mexico, November 3-5, 2021

in society. Blasphemy that leads to conflict between one group and another, of course, can tear the nation's unity (Anwar \& Haq, 2019).

Moderation of Islam in Arabic comes from the Arabic al-Wasathiyyah al-Islamiyyah. Al-Qardawi mentions several vocabularies with similar meanings including the words Tawazun, I'tidal, Ta'adul and Istiqamah. While in English as Islamic Moderation.(Muchtar et al., 2019) So Islamic Moderation is a view or attitude that always tries to take a middle position from two opposing and excessive attitudes so that one of the two attitudes in question does not dominate in one's thoughts and attitudes. In other words, a moderate Muslim is a Muslim who gives each value or aspect that contradicts a certain part no more than its due portion. The term moderation according to Khaled Abouel Fadl in The Great Theft is an understanding that takes the road. middle, that is, the notion is neither extreme right nor extreme left (Julia, 2020). ). Moreover, the community must be able to be moderate in living their diverse life, not by providing propaganda in various aspects. (Syatar et al., 2020).

Moderate is defined as an attitude or view that inevitably avoids extreme behavior or disclosure, or tends toward a central dimension or way. (KBBI, 589). Discourses on moderation have been the subject of debate among Indonesian Muslim scholars. In the analysis of Muhammadiyah scholar A. Najib Burhani, the label of moderation only serves as a shirt when it cannot explain its position in the central struggle of influence between Islamic hardliners and Islamic liberal groups. A characteristic of Moderate Islam is that Fazlurrahman is known as a Neo-modernist of Islam. Neo-modernist Islam tries to be in the middle and bridge the gap that exists between traditionalists who reject modernity and modernists who swallow the raw of Western modernism. The neomodernism movement struggles for how Muslims can face the challenges and challenges of modern civilization by remaining based on the original treasures of Islam. Azyumardi Azra defines radicalism as an attitude of the soul that results in actions that aim to weaken and change the established political order and usually in a violent way, and change the new system (Darajat, 2017).

Some of the principles inherent in Islamic fundamentalism movement as proposed by Azyumardi Azra. First, the principle of oppositionalism (understanding of resistance), against everything that is seen endanger the existence of religion, whether in the form of modernism, secularism, or governance Western values in general. Second, the rejection of hermeneutics. Third, rejection against pluralism and relativism, and the fourth rejection of development historical and sociological. (Darajat, 2017) That is, the development of society must adapt with the scriptures, not the other way around. level of religious understanding, Muhammadiyah is fundamentally radical, because it aims to make changes comprehensive understanding of various forms of Islamic beliefs and practices that have been mixed with heresy, superstition and superstition. It's just that, in actualizing this ideological radicalism, Muhammadiyah uses methods and approaches that persuasive efforts through education, health, social, and so on. Otherwise, liberalization of Muhammadiyah thought and practice was seen when he called for rejection of taklid to scholars and open the door of ijtihad. Muhammad too very responsive and adopting various forms of modern systems and institutions.(Darajat, 2017).

Based on a report from the Directorate of Information Application Control, Directorate General of Information Applications at the Ministry of Communication and Informatics, it shows that the most blocked content is on Facebook and Instagram, which is 8,131 content. Meanwhile, on Twitter there are 1,384 content. As for the content of radicalism and terrorism that was blocked on Google and YouTube as many as 678 content. Then, 614 content on the Telegram platform, 502 content on file sharing, and 494 content on websites (Wibowo, 2019).

Muhammadiyah is a movement for enjoining ma'ruf and nahi munkar, so the Muhammadiyah movement consistently conducts amar ma'ruf and nahi munkar. Muhammadiyah has always been at the forefront of supporting and defending pro-people government programs that bring benefit and prosperity to the people of Indonesia. (Anriani, Halim, Zainuddin, Wekke, 2018) However, Muhammadiyah also does not hesitate if there are government policies, state policies that deviate from the constitution and even deviate from religious values, then Muhammadiyah will not hesitate to become a criticizing force, that is amar ma'ruf and nahi munkar. (PP Muhammadiyah, 2015). In addition, Muhammadiyah is a movement that leads to Islam as the religion of Rahmatan ili 'alamin (Mahyuddin et al., 2020) This can be seen in the application of learning that has been done by Muhammadiyah educational institutions (Tamrin, 2019).

Islamic moderation can be understood as an attitude or behavior that always prioritizes the values of the middle way and does not overdo it. Moderate can also be interpreted as consistently being in the middle lane between textuality-rationality, social ritual and dogmatic-dynamic. (Idris, Willya, Wekke, 2020). In other words, moderate is a tolerance and compromise attitude in seeing differences. However, it also does not mean not having an attitude so as to justify or accept all differences without limits. This is certainly not a moderate attitude, but an attitude that is beyond reasonable (Fithriyyah \& Umam, 2018).

In the eastern part of Indonesia, there are Muhammadiyah universities whose majority of students are nonMuslim students, namely: Sorong Muhammadiyah University, Sorong Muhammadiyah Education University, STKIP 
Muhammadiyah Manokwari and Muhammadiyah University of Papua. As a higher education institution, the university has a major contribution in creating a climate of religious moderation for the Papuan people. Moreover, Papua is an area where conflicts often occur.

Muhammadiyah is a part of religious moderation on a global scale. Likewise in Papua. In this case, it can be seen with the establishment of the Universitas Pendidikan Muhammadiyah Sorong. Educational institutions become a means of dialogue on cultural and religious diversity. Including, educational institutions managed by Muhammadiyah, not only for Muslims. But also, across religions. Therefore, it is interesting for the author to write an article about Religious Moderation and Information Communication Technology Dissemination: The Practice of Muhammadiyah Papua Through Online Campaign.

\section{Method}

The research entitled Religious Moderation and Information Communication Technology Dissemination: The Practice of Muhammadiyah Papua Though Online Campaign uses an interpretative paradigm with a literature study approach. Stages of research (Darmalaksana, 2020) carried out by collecting library sources both primary and secondary. This study performs data classification based on research formulas. In the advanced stage, data processing and or reference citations are carried out to be displayed as research findings, abstracted to obtain complete information, and interpreted to produce knowledge for drawing conclusions. As for the interpretation stage, analysis or approaches are used, for example, philosophical, theological, Sufistic, exegesis, syarah, and others. the data collected will be analyzed in depth and then abstracted so that information is found in the research that makes the novelty in this research, it is hoped that the findings in this study can be useful both for institutions and society in general

\section{Result and Discussion}

The word 'wasathiyah' is taken from the term 'wasatha', 'wustha' which means middle, and became the term wasith-alwasith which means middleman. In the interpretation of al misbah it is explained that Muslims serve as the wasathan (middle) ummatan are moderate and exemplary, so that the existence of Muslims in the middle position is in accordance with the position of the Kaaba which is in the middle as well. The middle position makes humans impartial to the left and right, something that can lead humans to be fair. Mid position make someone can be seen by anyone in a different angle, and at that time he can be an example for all parties.

The discourse on Muhammadiyah, seems to have to present the figure of KH. Ahmad Dahlan as a central reformer in the field of education is second to none. This controversial figure in his era, was lived as the pulse of his people, who always struggled with everyday life under the shadow of the nobility, the colonizers, without being able to help the periphery. Its people are struggling with ignorance and colonialism, both in terms of education, economy, religion, and so on. It was the Muslims who at that time felt the pain of backwardness, let alone compete with the Dutch, they could not win against the native Christians alone. Seeing the people who are still struggling with economic backwardness, education, and understanding of religion, makes him concerned, so the first thing he did was to study Surat al-Maun and teach it to the students. The students are taught to practice the messages expressed and implied in the letter al-Maun. Surah liberation theology This al-maun was then implemented in the bil hal movement by providing compensation to residents in the vicinity, then the Oemat Penolong Kesengsaraan (PKO) was formed in a larger and wider spectrum. The second thing that became his concern was educational competition, with his initiative the religious education system was integrated with the general education system. Many circles ridiculed or even despised what he did. Then the third, the condition of the people who still carry out cultural traditions mixed with religions that tend to shirk, kurafat and superstition. Inspired by these three dimensions, his determination was made to form the Muhammadiyah organization in 1912.

The Indonesian nation is a country that has diversity. This diversity is the difference between ethnicity, ethnicity, culture, language, religion which is almost incomparable in the world. In addition to the six religions that are most widely embraced by the community, there are hundreds or even thousands of tribes, regional languages and scripts as well as local beliefs in Indonesia. Referring to data from the Central Statistics Agency (BPS) in 2010, the total number of tribes and sub-tribes in Indonesia was 1131, although in 2013 this number was successfully clarified by BPS itself, in collaboration with the Institute of Southeast Asian Studies (ISEAS), to 633. large tribal group (RI, 2019)

One consequence of this diversity is the emergence of radicalism that thrives in Indonesia. Syamsul Bakri sees that there are several factors that encourage the emergence of radicalism movements in Indonesia. First, the sociopolitical factor, this can be seen from the religious violence that appears more based on political and social phenomena, 
Proceedings of the International Conference on Industrial Engineering and Operations Management Monterrey, Mexico, November 3-5, 2021

not on the basis of actual religious phenomena. Azyumardi Azra emphasized that the deteriorating position of Muslim countries and the north-south conflict were the main drivers of the emergence of radicalism. Second, the religious emotion factor, namely a high sense of solidarity with fellow believers who are oppressed by certain groups. Groups or movements that appear in the name of religion openly show angry emotions based on a wrong interpretation of the religious cases that arise.(Tadjuddin et al., 2019). Third, cultural factors. This factor is a typical sentiment because Indonesia has a high level of cultural conflict. Groups in the name of religion often use aspects of tradition and culture as a tool to separate the concepts of religion and culture. Cultural traditions that are not in accordance with their religious understanding must be eliminated. As revealed by Musa Asya'ari that there is an effort by community groups to separate the cultural context from the religion. Fourth, the ideological factor is anti-westernization. Symbols originating from the thoughts of Western leaders must be destroyed for the sake of upholding Islamic law. Fifth, the government policy factor. Often government policies are not able to correct the growing frustration and anger of the people caused by ideological, military, and economic development factors from the big countries. This fact has urged the Indonesian government to immediately take a firm stance on efforts to moderate religion (Thoyyib, 2018).

\section{The practice of religious moderation through Muhammadiyah Papua}

Muhammadiyah is the oldest religious organization in Indonesia. Since its inception in 1912 by KH. Ahmad Dahlan, Muhammadiyah calls itself the tajdid (reform) movement. In terms of religious orientation, Muhammadiyah is basically a Salafiyah movement by carrying out purification or purification. In the field of aqidah, trying to clean the aqeedah of the people from things that are superstition and superstition that can lead to polytheism. In the field of worship, trying to clean the worship of the people from things that are heretical (Syamsuddin, 1995).

Muhammadiyah is an Islamic movement and da'wah amar ma'ruf nahi munkar, has Islamic faith and is based on the Qur'an and Sunnah, aspires and works for the realization the main, just and prosperous society that is blessed by Allah SWT, to carry out human functions and missions as servants and caliphs of Allah on earth (Husein, 2017).

In relation to the above ideals, it is not wrong if Muhammadiyah in an area or area it carries is a humanitarian and charitable mission. Da'wah bil hal is da'wah with real actions that include exemplary. For example, with real works of charity, the results can be felt concretely by the community as objects of da'wah. Da'wah bil hal was carried out by the Messenger of Allah, it is evident that when he first arrived in Medina what the Prophet did was build the Al-Quba mosque, uniting the Ansar and the Muhajirin. These two things are real da'wah carried out by the Prophet which can be said to be da'wah bil hal (Wekke, Arif, Zubair, \& Wardi, 2019).

Da'wah is not just rhetoric, but must be an example of action as a real da'wah for development. This is due to the increasingly widespread and complex needs of the community who need to receive da'wah. So, da'wah must be a "non-verbal community" or da'wah bil hal. Da'wah must experience decentralization of activities. He doesn't have to be in mosques, recitations, but also has to be downstairs, in slums, in hospitals, in theaters, in film studios, in music, on ships, airplanes, in centers of commerce, employment, in factories, in places of skyscrapers, in banks, in courts, and so on3. The spirit of da'wah bil hal was evident in the Muhammadiyah movement wherever it was founded. This will also be observed in this study, especially Muhammadiyah in Sorong City. (Wekke, Arif, Zubair, \& Wardi, 2019). Movement across the ages has two meanings. First, going through, undergoing, treading, and facing a period or situation from birth to the age of 100 years. Second, crossing or crossing borders, namely entering a new phase after the age of one century to the turn of the next century. The Islamic movement that is always istiqamah carries out the mission of da'wah and tajdid to realize the main civilization. The picture of Muhammadiyah development in the regions, especially in Sorong City, is not as easy as originally imagined. Maintaining existing assets, and maintaining and improving them is a challenge in itself. (Wekke, I. S., Arif, B., Zubair, A., \& Wardi, M. 2019).

In the reform era, new trends emerged from various political parties, interest groups, and religious movements that influenced the dynamics of national life. These new movements appear not only to fight for their own interests, but also to understand their teachings or ideologies, both moderate and radical. This new trend is a logical consequence of the era of openness, all of which claim to build a new order in the life of the nation and state in a better direction. However, it cannot be denied that the existence of these movements can also give birth to new social fragmentation which does not rule out the possibility of causing conflicts of sects and interests between fellow components of the nation, including conflicts between Muslims themselves. (Bahriani, M. M. D. 2020).

The presence of these new movements, for Muhammadiyah, certainly encourages the spirit of fastabiqul khairat to continue to build the quality of the people and nation. However, it must be acknowledged that the new development has provided more open opportunities for the entry of various understandings or interests, both political and religious in nature and unfavorable thoughts. Latief, \& Nashir, (2020). This purification of Islamic teachings takes the form of ijtihad in the context of religious cultural historicity, with an emphasis on business charities in the fields of education, health, and charity for orphans. The goal is to create a mardlatillah society, which is the implementation 
Proceedings of the International Conference on Industrial Engineering and Operations Management Monterrey, Mexico, November 3-5, 2021

of the principle of amar ma'ruf nahi munkar. In the context of this research, especially in the city of Sorong, Muhammadiyah began its existence by establishing educational facilities and orphanages as a place to start its movement in addition to other forms of general recitation.

Information technology Pillars of Religious Moderation in Indonesia In Indonesia, wasathiyah discourse or moderation is often described through three pillars, namely: moderation of thought, moderation of movement, and moderation of action The pillars of religious moderation can be mapped into three important interrelated pillars (Halim, Wekke, Zainuddin, Kamaruddin, 2018).

According to his explanation, Arzumardi Azra, Muhammadiyah from the beginning adhered to the principle of religious moderation. Although in 1912 there was no word "religious moderation", but in essence that is how Muhammadiyah describes it. The formulation of the 12 Characters of Islamic Moderation compiled in 2018 in Bogor at the World Conference of Muslims (KTT) is very much in line with the character of Muhammadiyah. Azyumardi Arza said at the 31st National Tarjih Seminar with the theme Moderation of Diversity in the Context of Advanced Indonesia. Theologically, Muhammadiyah was initially considered Jabariyyah. Although this understanding is unanimously considered heretical by the scholars. (Kardono, Wangga, \& Rochaety, 2019).

Azyumardi explained, actually Muhammadiyah has an Asy'ariyah ideology which has been updated with added value to the social work ethic. "Muhammadiyah's work ethic is very high. So it is different from Jabariyah understanding, "while in the field of fiqh, Muhammadiyah takes steps to return Islamic teachings to the Qur'an and As-Sunnah by developing ijtihad (Wahyudi, \& Noorsetya, 2017).

Relate to the esoteric world. The type of Sufism that is compatible with Muhammadiyah is Buya Hamka's modern Sufism which emphasizes the aspects of sincerity, qana'ah, and tawakal. Therefore, if we take the Sufism approach, then Muhammadiyah Sufism is Buya Hamka's model of modern Sufism. According to Azyumardi Azra's understanding that Sufism is not excessive, nor is it philosophical or speculative. (Setiani, \& Syauqi, 2020).

The first pillar is the moderation of religious thought (fikrah). In the context of Islam in Indonesia, the moderation of thought, among others, is shaped through the history of the process of Islamization which later forms an intellectual genealogy (Zulfa, 2018). Apart from the academic theoretical debates about when, where, how, and by whom the process of Islamization in Indonesia was carried out, Islamization in Indonesia provides a basis for thinking, both in theological aspects, fiqh, and morals/sufism as the implementation of ahlussunnah waljamaah understanding. Moderate religious thought, among others, is characterized by the ability to combine text and context, namely religious thought that does not solely rely on the truth of religious texts and imposes the submission of new realities and contexts on the truth of the text, but is able to dynamically dialogue between the two (Makbul, 2021). In other words, this moderation of Islamic thought is in a non-textual position, but at the same time it is not trapped in a way of thinking that is too free and ignores signs. The intellectual genealogy of the Nusantara ulema has clearly inherited this moderate intellectual tradition. This is formulated in the notion of ahlussunnah waljamaah-as developed in the tradition of thinking of Nahdlatul Ulama (NU), namely in the field of fiqh adhering to one of the four schools of thought (Hanafiyah, Malikiyah, Syafiiyah, and Hanabilah); in creed following Abu Hasan al-Ash'ari and Abu Mansur alMaturidi; in the field of Sufism following Al-Ghazali and Junaid al-Baghdadi. These figures are authoritative scholars whose opinions become the basis for thinking and acting.(Idris, Willya, Wekke, 2020)

The peaceful spread of Islam forms the character of a society that is tawasuth (moderate), tawazun (balanced), and tasamuh (tolerant). These characters eventually form a way of thinking and acting that prioritizes harmony and is not extreme in responding to various social developments. The thorny issues of nationality can be resolved without bloodshed. Indonesian people do not like extreme attitudes (tatharruf) which are usually difficult to negotiate in solving problems. Extreme characters only know "lose" and "win".(Haslinda, Anriani, Halim, Zainuddin, Wekke, 2018). While moderation will prioritize win-win solutions, everyone feels they have won. This attitude is recorded in the wisdom of the Javanese people as winning without ngasorake, winning without demeaning others. The second pillar is the moderation of the movement (harakah) which is based on the spirit of da'wah and amar ma'ruf nahi munkar which is based on the principle of making improvements, but must be done in good ways. The da'wah movement in the process of Islamization in Indonesia is carried out by prioritizing compassion (bil wisdom wal mau'idhatil hasanah), not by using violent means. Inviting to goodness (al-amru bil ma'ruf) must be done in a good way, as well as preventing munkar (an-nahyu 'anil munkar) must be done in a way that (not) brings new munkar (bighairil munkar). This is the principle of da'wah that underlies the development of Islam in Indonesia, which until now is embraced by 87.3 percent of the Indonesian people. The third pillar is the moderation of religious traditions and practices (alamaliah al-diniyah), which opens up space for creative dialogue between Islam and the traditions and culture of Indonesian society. Although religious practices require legitimacy from primary sources of Islam, the Qur'an and Hadith, Islam in Indonesia does not necessarily prohibit Islamic traditions and practices that are based on respect for community traditions. The tradition or culture in the fiqh proposal called al-'urf or al-'Ãdat is not simply suppressed 
Proceedings of the International Conference on Industrial Engineering and Operations Management Monterrey, Mexico, November 3-5, 2021

but cared for as long as it does not deviate from the values of Islamic teachings. This kind of religious practice later became the religious tradition of the Indonesian people (Laila, 2021).

Muhammadiyah Papua research on couple scale has also been carried out. Among them, research by Wekke, Arif, Zubair, \& Wardi, (2019) suggests that Muhammadiyah education is a means of da'wah. In addition, Wekke (2016) argues that pesantren can be a means of empowerment. Thus, it is not only a means to improve human resources. But at the same time, it becomes a means of community empowerment. Wekke (2015) also suggests that educational institutions in West Papua provide curriculum reinforcement.

\section{Conclusion}

The religious moderation campaign through information technology is an effort of Muhammadiyah universities in Papua and West Papua, which is Muhammadiyah's effort to create a tolerant society, especially in Papua and West Papua. There are at least three things behind the birth of this research: 1) the speed of the radicalism movement that accompanies religion in the digital world; 2) potential for conflict and SARA, especially in Papua and West Papua 3) the importance of strengthening religious moderation in Indonesia, especially through digital media. The results of the study show that Muhammadiyah Papua universities in campaigning for religious moderation function as a balancer in the digital world. That is, the narrative of religious moderation from the Muhammadiyah Papua university gives birth to a substantive and essential religious framing that is moderate and tolerant. By using a persuasive approach with a narrative of religious moderation, the values in the substance of Muhammadiyah's da'wah will be able to reach the community, with various da'wah tools and media, it is very likely that the future of the da'wah struggle in Papua will be brighter. Those related to SARA will be countered by da'wah with a moderate approach, which prioritizes the common good, is not extreme in seeing differences, and upholds the values of tolerance between religious communities.

\section{References}

Anwar, F., \& Haq, I. (2019). Religious Moderation Campaign Through Social Media At Multicultural Communities. Kuriositas, 12(2), 176-187.

Bahriani, M. M. D. (2020). Pengaruh Pemberian Penguatan (Reinforcement) terhadap Prestasi Belajar Peserta Didik dalam Bidang Studi Pendidikan Agama Islam di SMP Negeri Makassar. Journal Mistar, 1(1).

Darajat, Z. (2017). Muhammadiyah dan NU: Penjaga Moderatisme Islam di Indonesia. Provided by Hayula: Indonesian Journal of Multidisciplinary Islamic Studies Hayula: Indonesian Journal of Multidisciplinary Islamic Studies, 1(1), 79-94. https://doi.org/https://doi.org/10.21009/hayula.001.1.05

Darmalaksana, W. (2020). Metode Penelitian Kualitatif Studi Pustaka dan Studi Lapangan. Pre-Print Digital Library UIN Sunan Gunung Djati Bandung, 1-6.

Fithriyyah, M. U., \& Umam, M. S. (2018). Quo Vadis Ormas Islam Moderat Indonesia? Meneropong Peran NUMuhammadiyah di Era Revolusi Industri 4.0. Politea, 1(1), 15. https://doi.org/10.21043/politea.v1i1.4310

Harifuddin Halim, Ismail Suardi Wekke, Rasyidah Zainuddin, Syamsu Kamaruddin, A. B. (2018). Become Entrepreneurs : The Social Impact of Wind Power Plant Industry Project Become Entrepreneurs : The Social Impact of Wind Power Plant Industry Project. IOP Publishing, 175.

Haslinda B. Anriani, Harifuddin Halim, Rasyidah Zainuddin, Ismail Suardi Wekke, A. A. (2018). Fisherman 's Wife Role in Extending Household Income in Palu Gulf Fisherman's Wife Role in Extending Household Income in Palu Gulf. IOP Publishing, 156(012001 doi). https://doi.org/10.1088/1755-1315/156/1/012001

Husein, A. (2017). Dakwah Kultural Muhammadiyah Terhadap Kaum Awam. Ath Thariq Jurnal Dakwah dan Komunikasi, 1(1), 91-105.

Julia, A. (2020). Moderasi Beragama di Indonesia. In Literasi Moderasi Beragama di Indonesia.

Kardono, R. B. A., Wangga, M. S. E., \& Rochaety, N. (2019). Searching for Islamic Legal Norms Against Punishment of Child Cast Sexual Offenses. MUSLIM SOCIETIES (ICONIS) 2019, 2019109.

Laila, F. A. (2021). Moderasi Beragama dalam Media Sosial (Analisis Wacana Model Van Dijk pada Channel Youtube Najwa Shihab).

Latief, H., \& Nashir, H. (2020). Local Dynamics and Global Engagements of the Islamic Modernist Movement in Contemporary Indonesia: The Case of Muhammadiyah (2000-2020). Journal of Current Southeast Asian Affairs, 39(2), 290-309.

Mahyuddin, Pikahulan, R. M., \& Fajar, M. (2020). Peran Strategis IAIN Ambon dan IAKN Ambon dalam Merawat Toleransi Sosial dan Moderasi Beragama di Ambon Maluki. Kuriositas: Media Komunikasi Sosial Dan Keagamaan, 13(1), 103-124. 
Proceedings of the International Conference on Industrial Engineering and Operations Management Monterrey,

Mexico, November 3-5, 2021

Makbul, M. (2021). The Effect of Emotional Intelligence and Spiritual Intelligence on Learning Outcomes of Islamic Religion and Characteristics of Students at SMA Negeri 5 Makassar. International Journal of Social Science and Human Research, 04(04), 588-595. https://doi.org/10.47191/ijsshr/v4-i4-05

Muchtar, T., Wekke, I. S., Shuhufi, M., \& Thanh, P. (2019). Knowledge Discovery in Clinical Data. International Journal of Engineering and Advanced Technology (IJEAT), 8(6S2), 1121-1124. https://doi.org/10.35940/ijeat.F1293.0886S219

Muh. Idris, Evra Willya, Ismail Suardi Wekke, S. M. (2020). Peace Resolution in Education and Application on Information and Peace Resolution in Education and Application on Information and Communication Technologhy. International Journal of Advanced Science and Technology, 29(November 2021), 20-21.

PP Muhammadiyah. (2015). Tanfidz Keputusan Muktamar Muhammadiyah ke-47. In Pimpinan Pusat Muhammadiyah (pp. 139-140).

Setiani, A., \& Syauqi, M. L. (2020). The Perfection of Religion in the Qur'an: QS AlMā'idah verse 3 in the view of Ibnu 'Abbas and Hamka's Interpretation. International Journal of Social Science and Religion (IJSSR), 213232.

Syamsuddin, M. D. (1995). The Muhammadiyyah Da 'wah and Allocative Politics in the New Order Indonesia. Studia Islamika, 2(2).

Syatar, A., Amiruddin, M. M., Rahman, A., Makassar, U. I. N. A., Parepare, I., \& Alauddin, U. I. N. (2020). Darurat Moderasi Beragama Di Tengah Pandemi Corona Virus Desease 2019 (Covid-19). KURIOSITAS: Media Komunikasi Sosial Dan Keagamaan, 13(1).

Tadjuddin, N., Elfiah, R., Meriyati, M., \& Suardi, I. (2019). The Interaction of Children 's Early Moral Development Process through a Holistic Approach. 8(9), 126-142.

Tamrin, M. (2019). Al-Islam dan Kemuhadiyahan (AIK) Pilar Dakwah Islam Rahmatan Lil Alamin (Studi Pada Perguruan Tinggi Muhammadiyah di NTT). Ta'lim: Jurnal Studi Pendidikan Islam, 2(1), 69-87.

Thoyyib, M. (2018). Radikalisme Islam Indonesia. TA’LIM : Jurnal Studi Pendidikan Islam, 1(1), 90-105.

Wahyudi, C., \& Noorsetya, B. (2017). The Power of Inclusive Interaction in Resolving The Religious Conflict (An Interactional Case of JAI, NU, and Muhammadiyah Activists in Bandung City). KARSA: Journal of Social and Islamic Culture, 25(2), 457-483.

Wekke, I. S. (2015). Tradisi pesantren dalam konstruksi kurikulum bahasa Arab di lembaga pendidikan minoritas muslim Papua Barat. KARSA: Journal of Social and Islamic Culture, 22(1), 20-38.

Wekke, I. S. (2016). Religious education and empowerment: study on pesantren in muslim minority West Papua. MIQOT: Jurnal Ilmu-ilmu Keislaman, 37(2).

Wekke, I. S., Arif, B., Zubair, A., \& Wardi, M. (2019). The Role of Muhammadiyah Institution Towards Muslim Minority in West Papua. Jurnal Ilmiah Peuradeun, 7(1), 21-42.

Wibowo, A. (2019). Kampanye Moderasi Beragama di Facebook: Bentuk dan Strategi Pesan. Edugama: Jurnal Kependidikan Dan Sosial Keagamaan, 5(2), 85-103. https://doi.org/10.32923/edugama.v5i2.971

Zulfa, U. (2018). Empowering Pesantren: A Study of Al-Ghazali's Thoughts on Islamic Education. Walisongo: Jurnal Penelitian Sosial Keagamaan, 26(1), 225-251.

\section{Biographies}

Budi Santoso, Was born in Wonogiri, Indonesia. He is a student of the University of Muhammadiyah Malang in the PAI postgraduate program at the University of Muhammadiyah Malang 2021. His previous education completed his Masters education at the University of Muhammadiyah Ponorogo, Ponorogo in 2016 and two years before he had completed his undergraduate education at the same campus in 2014.

Ahsanul Inam, He was born on August 10, 1964. he has completed a Master Degree of Management at the University of Muhammadiyah Malang (1996) and a Doctor of Philosophy of Educational Management, Planning and Policy at the Faculty ofEducation University of Malaya Kuala Lumpur Malaysia (2009). He is the director of postgraduate, Universitas Muhammadiyah Malang.

Abdul Haris, He has graduated from IAIN Sunan Ampel in 1989 then Khartoum International Institute For Arabic Language in 1996 and doctorate at Maulana Malik Ibrahim State Islamic University in 2014. He is senior lecture in Universitas Muhammadiyah Malang. 
Proceedings of the International Conference on Industrial Engineering and Operations Management Monterrey, Mexico, November 3-5, 2021

Ismail Suardi Wekke is a lecturer at Postgraduate Program in the Department of Islamic Education, State Islamic Institute (IAIN) Sorong, Indonesia, where he serves as chair (2020-2021). Ismail was born in the village namely Camba. A village in Maros Regency, South Sulawesi, Indonesia. He is a lecturer at Postgraduate Program in the Department of Islamic Education, Institut Agama Islam Negeri (IAIN) Sorong, West Papua, Indonesia. 